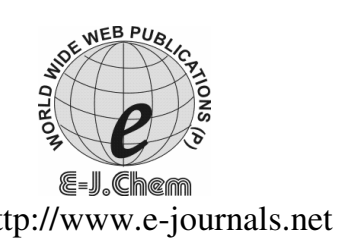

ISSN: 0973-4945; CODEN ECJHAO

E-Journal of Chemistry 2009, 6(S1), S515-S521

\title{
Determination of Phosphate in Water Samples of Nashik District (Maharashtra State, India) Rivers by UV-Visible Spectroscopy
}

\author{
SANJEEVAN J. KHARAT ${ }^{*}$ and SANJAY D. PAGAR \\ *P. G. Department of Chemistry, \\ HPT Arts and RYK Science College, Nashik-422005, India. \\ Chemistry Department, Arts, Commerce and Science College, \\ Dindori, District- Nashik, India. \\ ksanjeevan@dataone.in
}

Received 28 March 2009; Accepted 20 May 2009

\begin{abstract}
The major rivers of Nashik District (Maharashtra State, India) are Godavari, Kadawa, Girna, Punad and Mosam. The major water pollutant of Nashik District Rivers is Phosphate. The amount of phosphate has been determined by the molybdenum blue phosphorous method in conjugation with UV-Visible Spectrophotometer. The data has been analyzed by least square method. The more phosphate polluted river in Nashik district is Godavari. The least phosphate polluted river in Nashik District is Punad.
\end{abstract}

Keywords: Water pollution, Phosphate, Nashik district rivers, UV-Visible spectrophotometer, Molybdenum blue phosphorus method.

\section{Introduction}

The major rivers of Nashik District (Maharashtra State, India) are Godavari, Kadawa, Girna Punad, and Mosam. The major water pollutant of these rivers is phosphate. In Nashik District, the main crops like sugarcane, onion, cotton, main fruits like grapes and pomegranates, the main vegetables like tomatoes, radish and garlic carrots are cultivated. Many farmers use organophosphates insecticides including malathion, diarithion and parathion. A large amount of fertilizers, pesticides and herbicides used on crops, and the organo phosphate insecticides used on grapes, pomegranates and vegetable in the field may get washed by rain water and reach to the river through agricultural run off. Detergents are important contributor of phosphate. Huge quantities of detergents are used annually. Most of it flushed into the sewer systems from bathrooms kitchens, laundry's, factories, and other industrial establishments.

Phosphate reflects BOD (Biological Oxygen Demand), therefore the number microbes as Escherichia coli (bacterium) also increase tremendously ${ }^{1}$. The number Escherichia coli per unit volume of water is main parameter of water pollution. Phosphate affects degradation 
lead to oxygen depletion which affects (and even kills) fish and other aquatic decomposing plants are known to produce toxins as strychnine which kills animals including cattle. Phosphate insecticides cause irreveversible inhibition of the enzyme chlorine steerage. These agents are absorbed by all routes including skin, mucosa, and symptoms and include weakness, blurred vision, headache, giddiness, nausea and pain in chest ${ }^{2}$. Organo phosphates may cause harmful effects on wild life. They affect calcium metabolism in birds, which affects egg lying with egg shells and consequently reproductive failure ${ }^{3}$. In the present study, the amount of phosphate present in the water samples of Nashik District rivers has been determined by the molybdenum blue phosphorous method in conjugation with UV-Visible Spectrophotometer ${ }^{4,5}$.

\section{Experimental}

1. Molybdate solution: $12.5 \mathrm{~g}$ of sodium molybdate $\left(\mathrm{Na}_{2} \mathrm{MoO}_{4}, 2 \mathrm{H}_{2} \mathrm{O}\right)$ was dissolved in $5 \mathrm{M} \mathrm{H}_{2} \mathrm{SO}_{4}$ and diluted to $500 \mathrm{~mL}$ with $5 \mathrm{M}$ sulphuric acid (This is to be prepared fresh monthly $2.5 \mathrm{~g} \mathrm{Na}_{2} \mathrm{MoO}_{4} 2 \mathrm{H}_{2} \mathrm{O}$ dissolved in $5 \mathrm{M} \mathrm{H}_{2} \mathrm{SO}_{4}$ and diluted to 100 volumetric flask.

2. Hydrazinium sulphate Solution: $0.15 \mathrm{~g}$ hydrazinium sulphate dissolved in deionised water and diluted to $100 \mathrm{~mL}$ volumetric flask.

3. Potassium dihydrogen phosphate: Qualigens AR, purity $>95.5 \%$

4. Sulphuric acid: ( Qualigens, AR)

\section{Method}

The molybdenum blue phosphorous method in conjunction with UV-Visible spectrophotometer is a very sensitive method ${ }^{4,5}$ for the determination of phosphorus at $830 \mathrm{~nm}$. Phosphate in the sample can be determined at sub-ppb concentration at $830 \mathrm{~nm}$. Orthophosphate and molybdate ions condense in an acidic solution to form phosphomolybdic acid, upon selective reduction (e.g. with hydrazinium sulphate) a blue color is produced. The intensity of the blue color is proportional to the amount of phosphate initially incorporated into the heteropoly acid. If the acidity at the time of reduction is $0.5 \mathrm{M}$ in sulphuric acid and hydrazinium sulphate is the reluctant then the resulting blue complex exhibits a maximum ${ }^{6}$ absorbance at $820-830 \mathrm{~nm}$. Intensity of the color solutions is normally measured on a visible spectrophotometer.

\section{Field work}

Water samples of Godavari, Kadva, Girna, Mosam and Punad rivers were collected from eight different places. Water samples for analysis were taken from the collection sites in the month of April, in one liter capacity plastic bottles. Table 1 summaries the water sample collection sites of Godavari, Kadva, Girna, Mosam and Punad rivers.

\section{Calibration curve}

The calibration curve is necessary to establish a relationship between the absorbance and the phosphate content for spectrophotometer analysis. Standard $10 \mathrm{ppm}$ phosphate solution was prepared by dissolving $0.04393 \mathrm{~g}$ of Analytical reagent potassium dihydrogen phosphate in deionized water and diluted to $1000 \mathrm{~mL}$. From $10 \mathrm{ppm}$ solution, the $25 \mathrm{ppb}, 50 \mathrm{ppb}, 75 \mathrm{ppb}$, $100 \mathrm{ppb}, 125 \mathrm{ppb}, 150 \mathrm{ppb}, 175 \mathrm{ppb}, 200 \mathrm{ppb}$, solutions were prepared. These solutions were prepared as per Table 2. The absorbance of standard solutions of $\mathrm{KH}_{2} \mathrm{PO}_{4}$ were measured by using Shimadzu UV-Visible (1700) spectrophotometer at $830 \mathrm{~nm}$. The calibration curve is constructed by plotting absorbance values against concentration of standard solutions. The straight line graph passing through origin has been obtained. This confirms the validity of Beer's - Lamberts law 
Table 1. Water Sample collection sites of various rivers of Nashik District.

\begin{tabular}{|c|c|c|c|c|c|c|c|c|}
\hline $\begin{array}{l}\text { Sample Label } \\
\text { Collection Site } \\
\text { Godavari River }\end{array}$ & $\begin{array}{c}\mathrm{G}_{1} \\
\text { Gangapur- gaon }\end{array}$ & $\begin{array}{c}\mathrm{G}_{2} \\
\text { Someshwar } \\
\text { mandir }\end{array}$ & $\begin{array}{c}\mathrm{G}_{3} \\
\text { Asaramba-pu } \\
\text { ashram }\end{array}$ & $\begin{array}{c}\mathrm{G}_{4} \\
\text { Chopda } \\
\text { launs }\end{array}$ & $\begin{array}{c}\mathrm{G}_{5} \\
\text { Panchavati }\end{array}$ & $\begin{array}{c}\mathrm{G}_{6} \\
\text { Tapovan }\end{array}$ & $\begin{array}{c}\mathrm{G}_{7} \\
\text { Janardhan } \\
\text { swami }\end{array}$ & $\begin{array}{c}\mathrm{G}_{8} \\
\text { Saikheda } \\
\text { gaon }\end{array}$ \\
\hline Sample Label & $\mathrm{K}_{1}$ & $\mathrm{~K}_{2}$ & $\mathrm{~K}_{3}$ & $\mathrm{~K}_{4}$ & $\mathrm{~K}_{5}$ & $\mathrm{~K}_{6}$ & $\mathrm{~K}_{7}$ & $\mathrm{~K}_{8}$ \\
\hline $\begin{array}{l}\text { Collection Site } \\
\text { Kadava River }\end{array}$ & Hatoneregaon & Nilvandigaon & Padegaon & Valkheda & $\begin{array}{l}\text { Kadva } \\
\text { molungi }\end{array}$ & Lakmapur & Avankhed & $\begin{array}{c}\text { Pimpalg-aon } \\
\text { ketki }\end{array}$ \\
\hline Sample Label & $\mathrm{Gi}_{1}$ & $\mathrm{Gi}_{2}$ & $\mathrm{Gi}_{3}$ & $\mathrm{Gi}_{4}$ & $\mathrm{Gi}_{5}$ & $\mathrm{Gi}_{6}$ & $\mathrm{Gi}_{7}$ & $\mathrm{Gi}_{8}$ \\
\hline $\begin{array}{l}\text { Collection Site } \\
\text { Girna River }\end{array}$ & Abhona & Pale khudra & Kalwan & Bej & Lohner & Nimbola & Agharkh & Tehre \\
\hline $\begin{array}{c}\text { Sample Label } \\
\text { Collection Site } \\
\text { Mosam River }\end{array}$ & $\begin{array}{c}\mathrm{M}_{1} \\
\text { Anatapur }\end{array}$ & $\begin{array}{c}\mathrm{M}_{2} \\
\text { Taharabad }\end{array}$ & $\begin{array}{c}\mathrm{M}_{3} \\
\text { Sompur }\end{array}$ & $\begin{array}{c}\mathrm{M}_{4} \\
\text { Jaikheda }\end{array}$ & $\begin{array}{c}\mathrm{M}_{5} \\
\text { Asakheda }\end{array}$ & $\begin{array}{c}\mathrm{M}_{6} \\
\text { Nampur }\end{array}$ & $\begin{array}{c}\mathrm{M}_{7} \\
\text { Ambasan }\end{array}$ & $\begin{array}{c}\mathrm{M}_{8} \\
\text { Khakurdi }\end{array}$ \\
\hline $\begin{array}{c}\text { Sample Label } \\
\text { Collection Site } \\
\text { Punad River }\end{array}$ & $\begin{array}{c}\mathrm{P}_{1} \\
\text { Umbarg-aon }\end{array}$ & $\begin{array}{c}\mathrm{P}_{2} \\
\text { Suphala }\end{array}$ & $\begin{array}{c}\mathrm{P}_{3} \\
\text { Siddesh-war }\end{array}$ & $\begin{array}{c}\mathrm{P}_{4} \\
\text { Savarpada }\end{array}$ & $\begin{array}{c}\mathrm{P}_{5} \\
\text { Bhanadp-ada }\end{array}$ & $\begin{array}{c}\mathrm{P}_{6} \\
\text { Desrane }\end{array}$ & $\begin{array}{c}\mathrm{P}_{7} \\
\text { Mogbh-agni }\end{array}$ & $\begin{array}{c}\mathrm{P}_{8} \\
\text { Bhadha-van }\end{array}$ \\
\hline
\end{tabular}


Table 2. Preparation of standard phosphate solution.

\begin{tabular}{cccccc}
\hline $\begin{array}{c}\text { Volume of } \\
10 \mathrm{ppm} \mathrm{P}\end{array}$ & $\begin{array}{c}\text { Final } \\
\text { volume }\end{array}$ & $\begin{array}{c}\text { Conc. of } \\
\text { Phosphate, } \mathrm{ppb}\end{array}$ & $\begin{array}{c}\text { Volume of } \\
10 \mathrm{ppm} \mathrm{P}\end{array}$ & $\begin{array}{c}\text { Final } \\
\text { volume }\end{array}$ & $\begin{array}{c}\text { Conc. of } \\
\text { Phosphate, ppb }\end{array}$ \\
\hline 0.000 & 50 & 0 & 0.625 & 50 & 125 \\
0.125 & 50 & 25 & 0.750 & 50 & 150 \\
0.250 & 50 & 50 & 0.875 & 50 & 175 \\
0.375 & 50 & 75 & 1.000 & 50 & 200 \\
0.500 & 50 & 100 & & & \\
\hline
\end{tabular}

The slope of the line can be determined by using the equation.

$$
\text { Slope }=\sum \frac{(x-\bar{x}) \cdot(y-\bar{y})}{(x-\bar{x})^{2}}
$$

To calculate intercept of the line, the equation used is,

$$
\text { Intercept }=\bar{y}-m \bar{x}
$$

$$
\begin{aligned}
& \bar{x} \text { - mean value concentration. } \\
& \bar{y} \text { - mean value absorbance. }
\end{aligned}
$$

The absorbance of the solution can be expressed by straight line equation ${ }^{7}$.

$$
\text { Absorbance }=(\text { Slope } \times \text { Concentration })+\text { Intercept }
$$

Rearranging the equation (3), the concentration is expressed as

$$
\text { Concentration }=(\text { Absorbance }- \text { Intercept }) / \text { slope }
$$

By using equation (4) we can calculate the amount of phosphate present in the solution. Least square method can be used to calculate value of slope and intercepts.

\section{Results and Discussion}

Table 3 shows the absorbance, amount phosphate determined by Shimadzu UV-Visible (1700) Spectrophotometer, and calculated by equation (4) of water samples of Godavari River. From Table 3, it is cleared that, the sample $\mathrm{G}_{8}$ shows the higher value of phosphate (191 ppb by spectrophotometer and $192 \mathrm{ppb}$ by calculation). Sample $\mathrm{G}_{8}$ was collected from Saikheda Gaon. Sakhaida Gaon is $30 \mathrm{~km}$ away form the Nasik city. The higher concentration of phosphate at this site arises because of large industrial waste from Eklahara Thermal Power Station, and sewage, sludge water and water containing molasses form Nasik Sugar Factory. Phosphate level in the samples $G_{1}$ to $G_{8}$ increases.

Table 3. Absorbance and concentration of phosphate (by Instrument and Calculation) of water samples of Godavari River.

\begin{tabular}{cccc}
\hline $\begin{array}{c}\text { Water } \\
\text { Samples }\end{array}$ & Absorbance & $\begin{array}{c}\text { Amount of Phosphate } \\
\text { (By Instrument) }\end{array}$ & $\begin{array}{c}\text { Amount of Phosphate } \\
\text { (Calculated) }\end{array}$ \\
\hline $\mathrm{G}_{1}$ & 0.122 & 124.50 & 122.2 \\
$\mathrm{G}_{2}$ & 0.130 & 133.58 & 130.2 \\
$\mathrm{G}_{3}$ & 0.135 & 135.50 & 135.2 \\
$\mathrm{G}_{4}$ & 0.141 & 142.90 & 141.2 \\
$\mathrm{G}_{5}$ & 0.162 & 164.28 & 162.2 \\
$\mathrm{G}_{6}$ & 0.166 & 168.20 & 166.2 \\
$\mathrm{G}_{7}$ & 0.169 & 170.12 & 169.2 \\
$\mathrm{G}_{8}$ & 0.192 & 191.20 & 192.2 \\
\hline
\end{tabular}


The absorbance, amount phosphate determined by Shimadzu UV-Visible (1700) Spectrophotometer, and calculated by equation (4) of water samples of Kadva River are shown in the Table 4. From Table 4, it is cleared that the water sample $\mathrm{K}_{6}$ shows the higher value of phosphate (112.11 ppb by spectrophotometer and $111.2 \mathrm{ppb}$ by calculation). The collection site of sample $\mathrm{K}_{6}$ is Lakhamapur Gaon. This collection site shows higher concentration of phosphate in water sample because of M.I.D.C. area of Lakhmapur which includes Seagram Distilleries, Everest Ceremics, and McDowell distillery. From these industries, wastage solid and liquid, sewage reach Kadwa river water. In Lakmapur village, large hectors of agriculture sector is also developed and it produces tones of grapes and vegetables. For the grapes and vegetable crops, farmers use oragnophosphate as well as phosphate fertilizers. Therefore in heavy rainy seasons precipitates come into the Kadva river basin and hence the collection site $\mathrm{K}_{6}$ shows higher concentration of phosphate.

Table 4. Absorbance and concentration of phosphate (by Instrument and Calculation) of water samples of Kadva River.

\begin{tabular}{cccc}
\hline $\begin{array}{c}\text { Water } \\
\text { Samples }\end{array}$ & Absorbance & $\begin{array}{c}\text { Amount of Phosphate } \\
\text { (By Instrument) }\end{array}$ & $\begin{array}{c}\text { Amount of Phosphate } \\
\text { ( Calculated) }\end{array}$ \\
\hline $\mathrm{K}_{1}$ & 0.081 & 83.212 & 81.2 \\
$\mathrm{~K}_{2}$ & 0.084 & 83.751 & 84.2 \\
$\mathrm{~K}_{3}$ & 0.089 & 90.120 & 89.2 \\
$\mathrm{~K}_{4}$ & 0.091 & 91.543 & 91.2 \\
$\mathrm{~K}_{5}$ & 0.104 & 105.400 & 104.2 \\
$\mathrm{~K}_{6}$ & 0.111 & 112.110 & 111.2 \\
$\mathrm{~K}_{7}$ & 0.092 & 93.540 & 92.2 \\
$\mathrm{~K}_{8}$ & 0.093 & 94.650 & 93.2 \\
\hline
\end{tabular}

The absorbance, amount phosphate determined by Shimadzu UV-Visible (1700) Spectrophotometer, and calculated by equation 4 of water samples of Girna River are given in the Table 5. From Table 5, it is clear that the sample $\mathrm{Gi}_{5}$ shows the higher value of phosphate (102.11 ppb by spectrophotometer and $101.2 \mathrm{ppb}$ by calculation). The sample $\mathrm{Gi}_{5}$ was collected from the middle part of Girna river ( Lohner Gaon). At this site phosphate level in water sample is high because of Vasaka sugar factory at banking of Girna River. The polluted water with molasses of sugar factory dissolves in Girna river sides which contains higher concentration amount of phosphate. Girna River is less polluted as compared to Godavari and Kadwa.

Table 5. Absorbance and concentration of phosphate (by Instrument and Calculation) of water samples of Girna River.

\begin{tabular}{cccc}
\hline $\begin{array}{c}\text { Water } \\
\text { Samples }\end{array}$ & Absorbance & $\begin{array}{c}\text { Amount of Phosphate } \\
\text { (By Instrument) }\end{array}$ & $\begin{array}{c}\text { Amount of Phosphate } \\
\text { (Calculated) }\end{array}$ \\
\hline $\mathrm{Gi}_{1}$ & 0.068 & 69.840 & 68.2 \\
$\mathrm{Gi}_{2}$ & 0.070 & 71.0130 & 70.2 \\
$\mathrm{Gi}_{3}$ & 0.076 & 77.130 & 76.2 \\
$\mathrm{Gi}_{4}$ & 0.078 & 78.180 & 78.2 \\
$\mathrm{Gi}_{5}$ & 0.101 & 102.110 & 101.2 \\
$\mathrm{Gi}_{6}$ & 0.099 & 100.200 & 99.2 \\
$\mathrm{Gi}_{7}$ & 0.096 & 98.170 & 96.2 \\
$\mathrm{Gi}_{8}$ & 0.097 & 98.190 & 97.2 \\
\hline
\end{tabular}


Table 6 shows the absorbance, amount phosphate determined by Shimadzu UV-Visible (1700) Spectrophotometer, and calculated by equation 4 of water samples of Mosam River. From Table 6, it is understood that sample $\mathrm{M}_{7}$ shows the higher value of phosphate $(79.170$ $\mathrm{ppb}$ by spectrophotometer and $79.200 \mathrm{ppb}$ by calculation). The sample $\mathrm{M}_{7}$ was collected from Ambasan Gaon. Ambasan Gaon is nearer to Nampur, sewage and sludge of Nampur village dissolves in Mosam River. Hence, the sample $\mathbf{M}_{7}$ shows the higher amount of phosphate. Mosam River is less polluted than Girna River.

Table 6. Absorbance and concentration of phosphate (by Instrument and Calculation) of water samples of Mosam River.

\begin{tabular}{cccc}
\hline $\begin{array}{c}\text { Water } \\
\text { Samples }\end{array}$ & Absorbance & $\begin{array}{c}\text { Amount of Phosphate } \\
\text { (By Instrument) }\end{array}$ & $\begin{array}{c}\text { Amount of Phosphate } \\
\text { (Calculated) }\end{array}$ \\
\hline $\mathrm{M}_{1}$ & 0.055 & 54.124 & 55.2 \\
$\mathrm{M}_{2}$ & 0.062 & 63.125 & 62.2 \\
$\mathrm{M}_{3}$ & 0.063 & 63.870 & 63.2 \\
$\mathrm{M}_{4}$ & 0.068 & 68.140 & 68.2 \\
$\mathrm{M}_{5}$ & 0.077 & 78.164 & 77.2 \\
$\mathrm{M}_{6}$ & 0.078 & 79.168 & 78.2 \\
$\mathrm{M}_{7}$ & 0.079 & 79.170 & 79.2 \\
$\mathrm{M}_{8}$ & 0.078 & 78.191 & 78.2 \\
\hline
\end{tabular}

Table 7 presents the absorbance, amount phosphate determined by Shimadzu UVVisible (1700) Spectrophotometer, and calculated by equation 4 of water samples of Punad River. From Table 7, it is inferred that sample $\mathrm{P}_{7}$ shows the higher value of phosphate (72.91 ppb by spectrophotometer and $70.2 \mathrm{ppb}$ by calculation) The water sample $\mathrm{P}_{7}$ was collected from Mogbhagni Gaon which is nearer to Kalwan. Because of agriculture sector of Kalvan Gaon, the sample $\mathrm{P}_{7}$ shows higher concentration of phosphate. Punad River is less polluted than other rivers of the Nasik district. Comparative graph of higher amount of phosphate and the collection sites of higher polluted areas of various rivers of Nasik district is shown in Figure 1

Table 7. Absorbance and concentration of phosphate (by Instrument and Calculated) of water samples of Punad.

\begin{tabular}{cccc}
\hline $\begin{array}{c}\text { Water } \\
\text { Samples }\end{array}$ & Absorbance & $\begin{array}{c}\text { Amount of Phosphate } \\
\text { (By Instrument) }\end{array}$ & $\begin{array}{c}\text { Amount of Phosphate } \\
\text { (Calculated) }\end{array}$ \\
\hline $\mathrm{P}_{1}$ & 0.051 & 52.12 & 52.2 \\
$\mathrm{P}_{2}$ & 0.053 & 54.63 & 53.2 \\
$\mathrm{P}_{3}$ & 0.062 & 63.87 & 62.2 \\
$\mathrm{P}_{4}$ & 0.068 & 68.14 & 68.2 \\
$\mathrm{P}_{5}$ & 0.069 & 68.16 & 69.2 \\
$\mathrm{P}_{6}$ & 0.069 & 69.74 & 69.2 \\
$\mathrm{P}_{7}$ & 0.070 & 72.91 & 70.2 \\
$\mathrm{P}_{8}$ & 0.071 & 71.19 & 71.2 \\
\hline
\end{tabular}




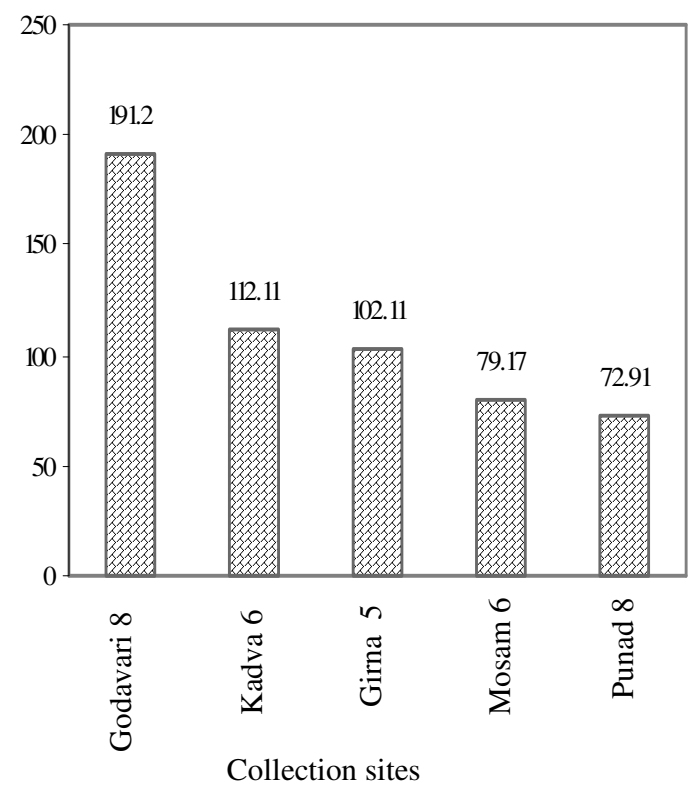

Figure 1. Comparative graph of higher amount of phosphate and the collection sites of higher polluted areas of various rivers of Nasik District.

\section{Conclusions}

1. Godavari river is largly polluted by phospahte than other rivers of the Nasik district while Punad River is less polluted.

2. Decrease in order of phosphate pollution of Nashik district river is Gdavari > Kadva > Girna $>$ Mosam > Punad

\section{Acknowledgement}

SDP thanks Dr. V. B. Gaikwad, Dean of Science faculty, Pune University, and Principal of KTHM College, Nashik for providing the Environmental Science Lab for experimental work.

\section{References}

1. Odum E P, Foundation of Ecology. W. B. Sounders, Philadelphis, 1971.

2. Higgihs I J and Burns R C, The Chemistry and Micobiology of pollutions London Academic Press, 1975.

3. Pawar K R, $1^{\text {st }}$ Ed., Environmental Awarness, Pune University, Nirali Publication, Pune, 2004, 5.1-5.8.

4. Bassett J, Denny R C, Jeffery G H and Mendham J, Vogels Text Book of Quantitative Inorganic Analysis, $4^{\text {th }}$ Ed., UK., 1979.

5. APHA, AWWA, AND WEF, Standard methods for the Examination of Water and Wastewater, $19^{\text {th }}$ Ed., Washington, DC, American Public Health Association, 1995.

6. Pittman J J, Zhang H, Schroder J L and Payton M E, Soil Science and Plant Analysis, 2005, 36, 1641-1659.

7. Hongg R and Ledolter J, Engineering Statistics Macmillan Publication, New York, 1987, 187-188. 


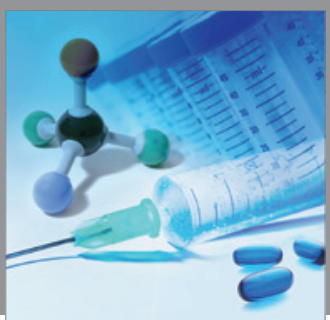

International Journal of

Medicinal Chemistry

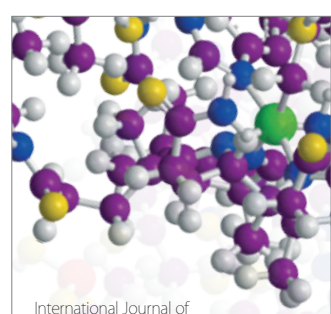

Carbohydrate Chemistry

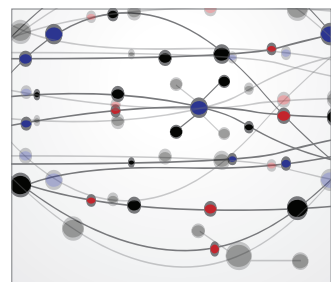

The Scientific World Journal
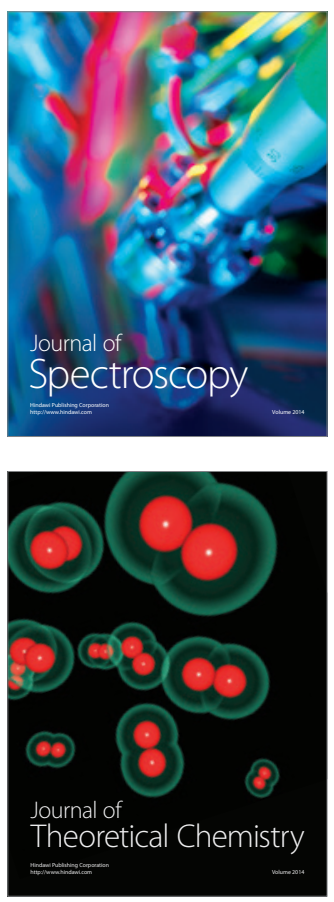
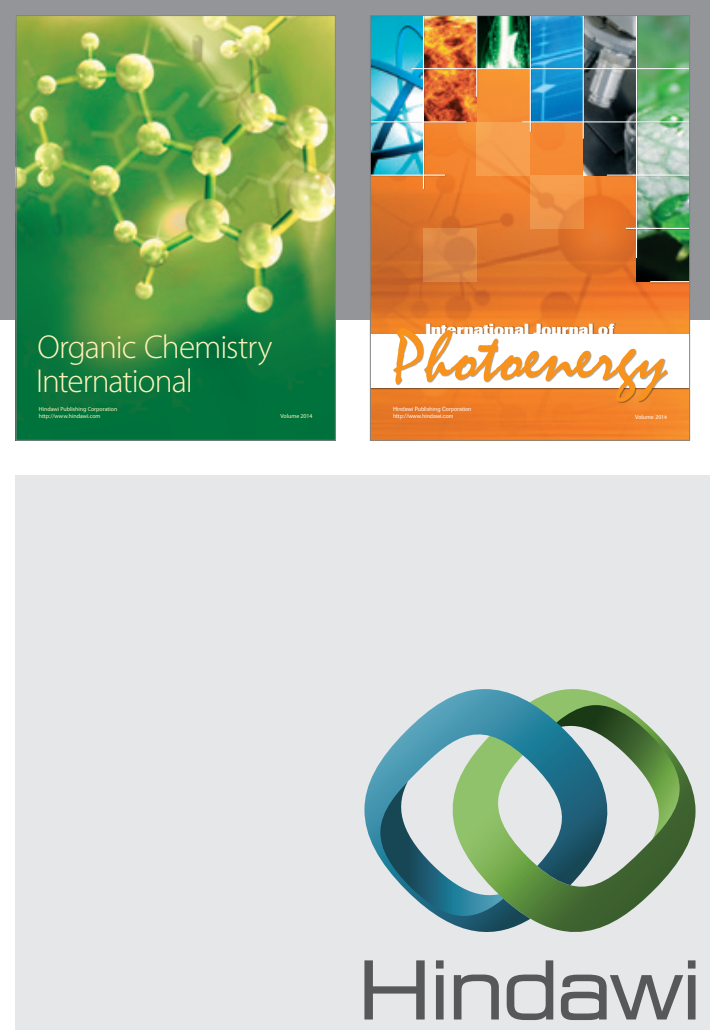

Submit your manuscripts at

http://www.hindawi.com
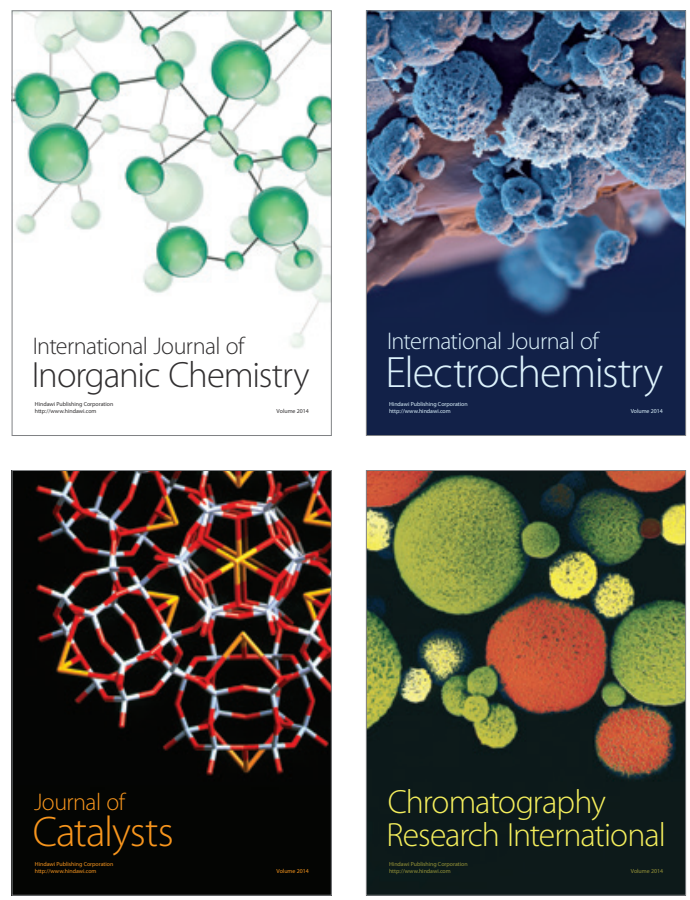
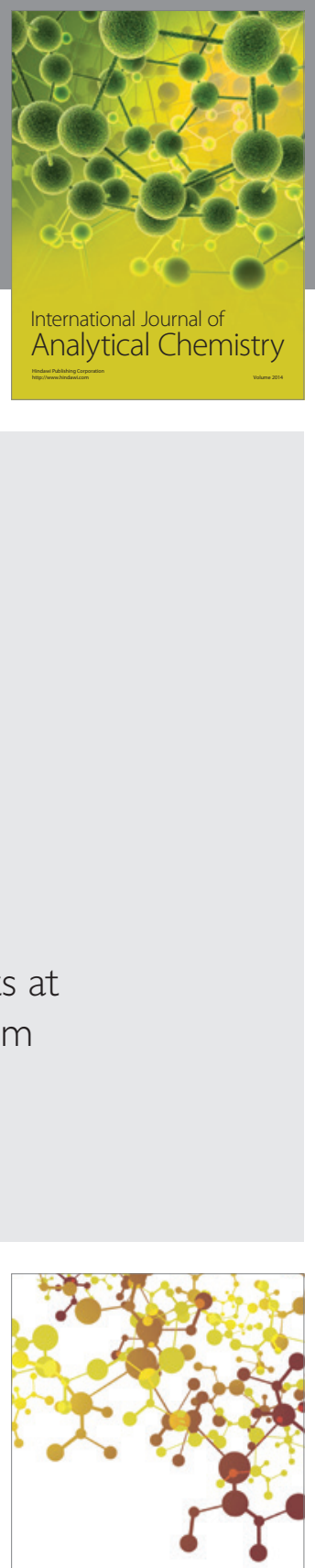

Journal of

Applied Chemistry
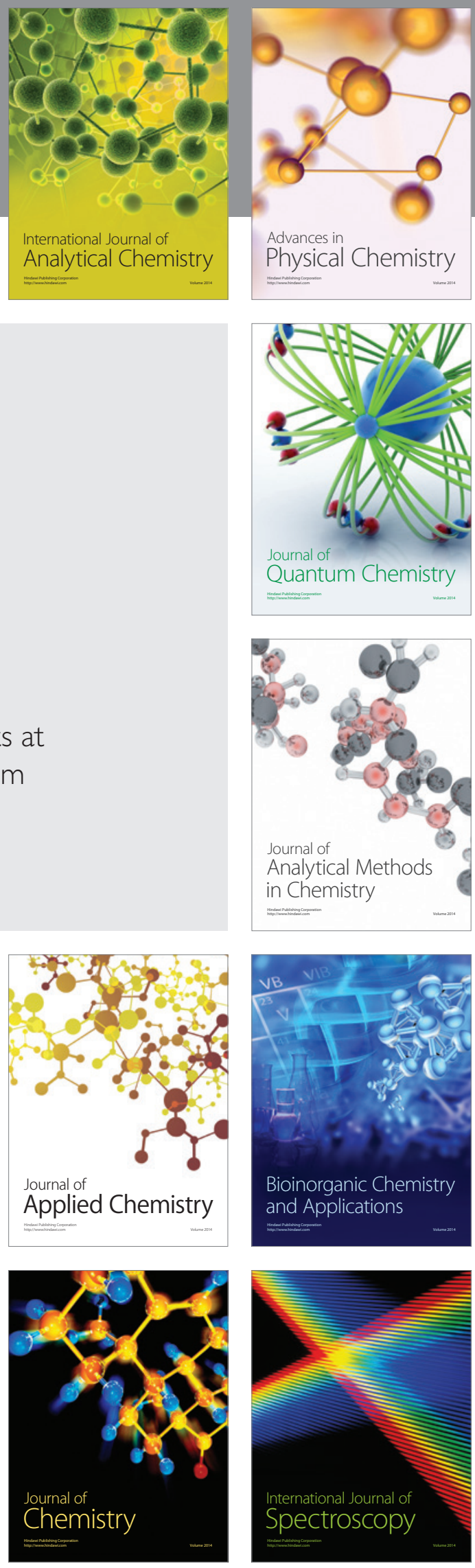